[Vaughan, K. (2002). Daring to be Different: The Rise and Fall of Auckland Metropolitan College. New Zealand Annual Review of Education, 11, 85-103]

\section{Daring to be Different: The Rise and Fall of Auckland Metropolitan College}

\section{KAREN VAUGHAN}

\section{Abstract:}

In December 2001, Auckland Metropolitan College (Metro), the only state-funded alternative secondary school in New Zealand, closed after eight highly critical ERO reviews in eight years. Despite support from its own community, other schools, and the Schools Support Programme, Metro closed amidst long-standing confusion over its status and role in the New Zealand education system. This article explores Metro's origins and the tensions between state regulation and innovative schooling within a quasi-market policy context. The article argues that Metro's ability to remain at the cutting edge of schooling was compromised by changes to, and gaps in, education policy, and that further research into alternative education, beyond the conception of it as a second chance option, is vital.

Kids like us rebel against school. But at Metro, the school rebels with you (6th form Metro student, 1998)

A $\mathrm{t}$ the end of the fourth term in 2001, Auckland Metropolitan College (Metro), the only state-funded alternative secondary school in New Zealand, closed its doors for the last time. The Minister of Education announced his decision to close Metro on November 29, 2001, after almost six years of agonised debate and publicity over the school's future, involving the Ministry of Education, the Education Review Office (ERO), and Metro supporters. It was the end of an era for the school whose motto was: Dare to be Different! Learn to Make a Difference!
86 Karen Vaughan

\section{A History of Criticism}

With eight negative ERO reviews in just eight years, beginning in August 1992, Metro had become one of the most reviewed schools in New Zealand. With its first recommendation of closure in February 1996, ERO stated that at Metro there were "unreasonably low levels of student attendance", plus a lack of "procedures to promote high quality staff performance", and recorded "the Board's failure to meet its obligations as stated in the National Education Guidelines 1993" (Education Review Office, 1996a). ERO claimed that Metro's deficiencies were "long-standing", ${ }^{1}$ stating that it was "not confident that the present board, managers and staff have the will or the capacity to bring about the required change." ERO also claimed:

The school has become a school of last resort for students and parents.... The school has retained its original philosophy and structures and has tried to make such students fit them. It has not successfully adapted its programmes, management style or teaching methods to meet the needs of its present students...there is little evidence that the majority of students are being educated as intended for all State school students. (Education Review Office, 1996a, p. 5)

ERO's criticisms of Metro were similar in its subsequent June 1998 review, and it recommended closure a third time ${ }^{2}$ in its 2000 report. The final ERO report on Auckland Metropolitan College made it clear that this review was a "last chance" one for the school, after the Secretary for Education had written to the school Board of Trustees the previous September, stating that closure would be initiated if the next ERO review did not indicate significant school improvements. Finally in August 2001, ERO's last recommendation to close Metro was acted upon decisively by the Ministry of Education.

Metro's immediate community of parents and students did not want the school to close. They argued persistently that, despite ERO's contention that student learning needs were not being addressed, Metro did meet their (learning) needs. But they claimed these were simply different from the academic learning needs upon which the Ministry of Education and ERO tended to focus. There was no division within the Board of Trustees or between staff and director. School staff vigorously defended their school, making submissions to the Secretary of Education, taking any available legal steps to remain open, seeking support from Members of Parliament and the educational community, 
and even holding a protest march against closure in Auckland's Queen Street. The Metro Board of Trustees and management also recognised the need to further develop its alternative philosophy into coherent school policies, and called for more time and assistance to do this. What the school found most problematic of all was that it was reviewed by ERO, not as an alternative school, but as a mainstream one. However, ERO had no mandate to do anything else; although Metro was known around New Zealand as alternative, its legal status was actually as a secondary State provider of education. No resolution of this tension between the "understanding" that Metro was alternative and a legal status which was identical to all other New Zealand state schools (and thus did not allow it to be assessed on its own terms alone), was ever reached within the Ministry of Education or between the Ministry of Education and Metro.

Other schools in Auckland, canvassed by the Ministry of Education in both 1997 and 2001, signalled their opposition over the potential closure of Metro, arguing that Metro met certain needs in the community. In 1997, of the 35 responses to the Ministry of Education's letter seeking opinion on Metro's possible closure (50 percent of the schools canvassed), there was great support (71 percent) for the school to stay open. In 2001, when the Ministry of Education canvassed schools again (this time 67 schools), they got 20 responses, but 80 percent of those responses also wanted the school to stay open.

In 1997 Metro had joined the Schools Support Programme and worked with Ministry-contracted consultants. In 1998 Metro accepted a Ministry of Education Agreement on required improvements and a repayable loan to bail the school out of financial difficulties incurred as a result of poor management and the initiation of a related legal dispute with one staff member. Metro also accepted a financial controller and a Ministry-appointed monitor to oversee them for two years. Metro took on a new (Ministry-approved) director from outside the school in 1999 who, alongside the Board of Trustees and Ministry monitor, updated school policies and implemented various management, attendance, and student achievement schemes. However while Metro eventually met most of ERO's governance-related criticisms with new systems, acceptable to both ERO and the Ministry, issues of low attendance and teaching quality were raised again and again by ERO between 1995 and 2001. In the end, the school was unable to demonstrate to ERO's satisfaction that it was providing a quality education for its students.
Why wasn't the Schools Support Programme successful in bringing Metro up to standard? Why wasn't the issue of Metro's legal status (or at least the criteria for evaluating it) ever addressed and resolved? How had a school noted for previous innovation and attention to the individual managed to fail in these times of celebrating enterprise and individualism? What went wrong?

\section{Intimations of Innovation}

Metro opened in February 1977 after Illich-inspired founder, David Hoskins, and the then Minister of Education, Hon Phil Amos, had discussed the possibility of an "experimental" and "alternative" school which would fit with the Department of Education's policy of integrating schools more closely with their community (see letter of November 15, 1974). The opening was backgrounded by the many alternative schools throughout Britain and the United States in particular, which were based on ideals about active learning, recognition of individual differences between students, co-operative class planning by teachers and students, and an attempt to make learning at school more directly related to "real life" outside school. By 1970, in New Zealand, there was marked interest (particularly amongst the middle class) in non-streamed approaches to class organisation, the inclusion of Maori culture and language, wide curriculum choice beyond the "basics", and pastoral disciplinary practices (as opposed to corporal punishment) based on behaviouralism (Middleton \& May, 1997). Auckland already had two private alternative schools, ${ }^{3}$ opened as a result of parent dissatisfaction with state schooling, and an interest in a child-centred, parent-involved, flexible learning environment (Papp, 1976). Hoskins' school was to be a "a redefinition of the form of the school", designed to free "the student from the 'dehumanisation' found in the isolation of the traditional school from the community and in the restriction of the timetable which predefines when learning will occur." (Hoskins, 1975, p. 42).

Metro was based on the Parkway Programme "school without walls" in the United States, which was premised on the idea that learning cannot be forced, and therefore student choice and life experience should be a cornerstone of any school programme (Bremer \& von Moschzisker, 1971). Parkway Programme classes were community based (and often community taught) and held in buildings all over Philadelphia; the school itself had no fixed location except a 
rented hall for a weekly school meeting. Students planned their own courses and some such as "Women in American History" and "Black history" often included an element of radical social critique (Parkway Programme, 1974). Metro was to be a sister school to Four Avenues School in Christchurch, another "school without walls" which had opened in $1975 .{ }^{4}$

Metro was established under Ministerial Approval Clause $12,{ }^{5}$ which emphasised that Metro was about "widening the variety of education available to Auckland pupils" (Mann, 1989). The clause also instructed Metro to conform to syllabus requirements in the Education (Secondary Instruction) Regulations. While letters between Hoskins, the Minister of Education, and the Chief Inspector of Education show clearly that Metro was intended as an alternative to mainstream schools, there was never anything included in the education legislation to support this specifically, and Metro opened as a state funded school under the governance of Penrose High School. ${ }^{6}$

Metro never realised its "school without walls" aims and Hoskins lost control over the school's direction early on. After the school was gazetted, as a newly-qualified teacher applicant, Hoskins could not have any say over the school's development, nor could he be the school director. The anticipated high level of community involvement never eventuated, due to what the first director of Metro described as a restrained economic climate and students' desires for exam-oriented courses (Begg, 1979, p. 1). Differences between Begg and Hoskins in the interpretation of student choice as it related to the school philosophy also contributed to Metro shifting away from Hoskins' original vision. Metro was also so popular and overcrowded upon opening that the Department of Education relocated the school to premises with classrooms and grounds the following year, so that it became much more a school with walls. Hoskins resigned within eighteen months. ${ }^{7}$

Despite these departures from Hoskins' vision, Metro was hailed as a leader in many aims and initiatives now common in secondary schools. Long before Tomorrow's Schools, parental and community involvement with the school, democratic decision-making, and the school-work interface had been a cornerstone of Metro policy and activity. Metro had been commended by ERO's predecessors, the Department of Education inspectors, for these factors, as well as for the:

- sense of belonging and respect at the school

- $\quad$ supportive learning environment created by teachers
- advanced commitment to gender equality through the variety of non-stereotypical work experience placements

- competence and commitment of the teachers. (1986)

There were no uniforms, corporal punishment or detentions at Metro, and teachers and students there addressed each other on a first-name basis. Students were able to specialise in particular interests, particularly the creative arts where the school was well known for producing a number of actors, dancers, artists, musicians, and composers. Many gay, lesbian, and bisexual young people, and students subject to bullying at other schools over their political beliefs or perceived "difference" from others, found a safe haven at Metro. ${ }^{8}$ Throughout the seventies and early eighties, with no school enrolment zone or restrictions to entry, there had been a waiting list for students to enrol there. In the first few years of Metro's existence, there was even a waiting list for teachers wanting to work there.

At Metro there had always been a great degree of flexibility around curriculum, timetabling, and attendance, with vertical form classes and a curriculum that had over the years included "popular culture" subjects, from Witchcraft and Car Owning (Auckland Metropolitan College, circa 1985) to Star Trek and Massage (Education Review Office, 1996a). Students participated in decision-making at all levels through a one-person, one-vote school meeting which was held twice weekly and could also be called spontaneously as an immediate response to a particular event or crisis in the school. Students as well as staff chaired meetings and voted on curriculum initiatives and decisions about allocation of resources and the annual budget. Students were also represented on interview committees for staff appointments. Thus teachers applying for work at the school could expect to face questions from, and be evaluated by, the students they may later be teaching.

During the late eighties, as Tomorrow's Schools' (1989) policies devolved responsibility and accountability for administrative and governance matters to all schools, Metro began to attract a greater share of "at risk" students expelled or suspended from other schools. As a result the school roll tended to fluctuate even more, as at risk students tended to arrive and leave Metro at various times during the year, making student assessment, course planning, and developing a cohesive school philosophy and direction difficult. By the mid-nineties, Metro was well-established as a decile five "sink" for at risk students" which other schools, operating in a quasi-market to the extent that responsibility for operations was devolved to each school with limited 
resources, did not want. This left Metro in the unenviable position of trying to meet the needs of two distinct groups of students - the non-conformist and the at risk. By 2001, at least one Ministry consultant identified Metro's open (non-zoned, non-selective) enrolment policy and its acceptance of both non-conformist and at risk students as being incompatible (Tennant, 2001). As the at risk students became the majority, notions of personal responsibility and individual freedom of choice integral to Metro's philosophy became increasingly difficult to sustain. Many at risk students showed little interest in participating in school and school meetings, or exercised their democratic rights in inappropriate ways.

\section{Deschooling Auckland}

The questioning of the legality of some of Metro's policies, the confusion over the school's status, and the lack of clarity over the support for Metro by the Ministry of Education, are all rooted in the education policies under which Metro emerged, and was then effectively deserted. Several factors converged to make this possible the collegial relationships between teachers, schools, and the government pre-1989, and their replacement in 1989 with detached audit procedures; the original background of educational thinking related to radical sociological theory which was later overtaken by a trend with particular definitions of school effectiveness; uncertainty over the (limits to the) roles of ERO and the Ministry of Education post-1989; and finally, post-1989 market conditions that left Metro trying to meet the needs of two specific groups of students who, while not entirely homogenous within themselves, had competing needs, some for less-directed learning opportunities, some for more-directed learning opportunities.

Both the Department of Education Inspectorate in 1986 and the first ERO review of Metro in 1992 referred to Metro as an alternative school in the statistical sections of their reports (Department of Education, 1986; Education Review Office, 1992). ERO reports subsequent to that of 1992 dropped the statistical section reference to Metro's alternative status. Instead, ERO painted Metro as an alternative school which no longer led the school community, since other schools had become, in some ways, more like Metro.

mainstream secondary schools have changed and many have incorporated some of the features that made Metro different. In many schools students have more choice about their dress; they take advantage of a wide range of curriculum, especially in the senior school; they are supported by strong guidance and counselling systems; and they participate in democratic decision making at many levels from student councils to boards of trustees. Conversely, as a result of pressures to meet its legal responsibilities, the Metro Board has introduced various management systems that are similar to those in mainstream schools. As a result many of the students who would have been attracted to Metro in the past now have many more suitable schools from which to choose. (Education Review Office 1996b, p. 3)

Metro had become both too alternative and not alternative enough. Ironically, the first director commented in his Report to the Board that although Metro was different from other schools, there was nothing Metro was doing that couldn't be done by other schools (Begg, 1979).

In its later reports ERO recognised that while Metro had no contractual arrangement with the Crown to provide alternative education, Metro did in fact do this, so the issue was one of whether the Crown would recognise it or not. ERO reiterated the issue raised by a facilitator appointed to Metro in 1996, who recommended that the Ministry of Education decide whether or not it would fund alternative models of school and that Metro could not work through those issues on its own. Although that facilitator attempted to engage with the issue of alternative provision of education and the status of the school, he was not successful in bringing about improvement in management at Metro (Educational Review Office, 1998) and from 1997 onwards, governance and management were the issues upon which the Ministry of Education's Schools Support Programme and monitor appointed to Metro focussed. Subsequent reports from ERO show that while Metro and its consultants were reasonably successful in this area, there were still contradictions apparent in practices at the school as it attempted to maintain an alternative philosophy in the face of pressure to deliver on mainstream requirements as well as perform a role similar to an activity centre.

The school's curriculum deficiencies are underpinned by the mismatch between national curriculum requirements and the commitment of the board and staff to being an alternative school...the board and staff have failed to clearly define their understanding of alternative education. (Education Review Office 2001b, p. 5) 
That last report on Metro from ERO stated that its findings were the same as those of the previous six reviews, and claimed to see "no purpose in undertaking further discretionary reviews of this school" (Education Review Office, 2001b, p. 4). The report itself, minus the statistical information and summary history at the beginning, barely ran to three pages, since ERO clearly believed that everything that could be said about Metro had already been said in its previous reports. To the extent that there seemed to be little commitment shown by the Ministry of Education (or ERO - though not necessarily its responsibility) to undertake an exploration into alternative education (and the deeper issues related to Metro), this was probably true.

\section{Tomorrow's Schools, Yesterday's School}

When the wide-ranging education reforms of Tomorrow's Schools came into force in October 1989, Metro appeared to exemplify many of Tomorrow's Schools' principles and aims, particularly where they had been backgrounded by Treasury criticisms of the economy and the education system. ${ }^{10}$ Metro had long involved students and parents on its board and management committees. Metro could be seen to be enterprising in its diverse curriculum options and flexible in its timetabling possibilities and decision-making structures. It could be seen as providing freedom of choice to students on matters of attendance and course planning, and transparent in its staff employment and budget allocation processes scheduled in democratic school meetings. It provided opportunities for life-long learning in its enrolments of teenage mothers, returning adult students and at risk or second chance students, as well as the school's innovative careers, life-skills, and health programmes. Metro's submission to the Secretary of Education, contesting ERO's two 1996 recommendations of closure, cited Administering for Excellence (and other Ministerial working party reports on the compulsory school sector) in definitions of individual competence as being "encouragement of initiative, personal responsibility, and entrepreneurial abilities" and the claim that if people are free to choose, a co-operative partnership between community and learning institutions is possible. Metro claimed that it was fostering these values and activities through its attitude towards its students and focus on introducing students to democratic practices and procedures through the school meeting (Auckland Metropolitan College, 1997).

However the legislation resulting from Tomorrow's Schools effectively legislated against many of the freedoms and personal responsibilities that Metro aimed to foster in its students through its particular style of democracy and diverse curricular activity. Three month before the new systems and lines of accountability of Tomorrow's Schools became law, confusion over Metro's philosophy as alternative was highlighted in an independent report. This report was commissioned by Penrose High School, Metro and the Department of Education (Mann, 1989) as tensions between Penrose High and Metro grew increasingly strained over differing notions of what counted as attendance (either in class or just at school) and Metro's desires for independence from Penrose High, which it saw as obstructing its alternative operations.

The independent report recommended Metro ready itself for Tomorrow's Schools by defining its purpose and function within a Charter that would then become the yardstick for its accountability (Mann, 1989, p. 4). For whatever reason, the school did not appear to take this on itself and there was no official support for this by the Department of Education, about to become the Ministry of Education. In fact Metro's post-1989 school charter was left unsigned by the Crown until reported on in 1998 by ERO. It was then rewritten by the school.

ERO's 1992 report noted Metro's desire for independence from Penrose but also raised concerns that some Metro staff had lost sight of the fact that Metro was established to provide alternative learning opportunities within the state system, rather than being "an alternative to a school". ERO also noted that the management committee had yet to acknowledge its obligation of accountability, let alone ensure systems of governance, administration, and leadership beyond those of simply ratifying the outcomes of school meetings. These at times had resulted in unlawful and inappropriate decisions being made through the voting patterns of students who constituted the majority of voters (Education Review Office, 1992). ${ }^{11}$

The "understanding" about Metro's alternative character which existed between Metro and the Department of Education had been possible in the context where teachers and Department of Education inspectors shared a collegial relationship. This relationship changed in 1989 when ERO was established ${ }^{12}$ under the State Sector Act 1988, rather than the Education Act $1989,{ }^{13}$ reflecting a general reorientation of the education system away from being a public good, with a new emphasis on such matters as contribution to the economy, efficiency, and accountability. The promotion of excellence in schools was paramount and linked to a notion of accountability which emphasised audit (detached and neutral evaluation) over professional forms of 
accountability, in order to eliminate provider capture, where the suppliers of state service were deemed to be pursuing their own interests. Quantitative measures of compliance were favoured over qualitative measures since the latter were thought "to play into the hands of self-interested organisations and professionals, including teachers" (Robertson, Dale, Thrupp, Vaughan \& Jacka, 1997, p. 23).

Putting into practice the imperative to avoid provider capture, alongside efficiency and accountability, resulted in the Ministry of Education and ERO having quite separate roles and functions. The Ministry provided policy advice and purchased education services as a principal on behalf of the Government. ERO's assignment, on the other hand, was to audit and assure the Crown's continued investment in education. Being a government department in its own right and lacking an advisory capacity immediately set ERO apart from its predecessor, the Department of Education Inspectorate. ERO's responsibilities were premised on its distance from both the schools and the central policy and funding authority - the Ministry of Education. ${ }^{14}$ Suddenly the professional and collegial relationships with the Department of Education, upon which Metro relied, became shaky.

Not only were the roles of the Ministry of Education and ERO quite separate but they were also in tension, competing for resources, authority, and influence within the education sector. Confusing and sometimes contradictory definitions of ERO's scope and responsibilities under the 1989 Education Act (Robertson et al., 1997) had combined with a relationship with the Ministry of Education that Jesson described as "a deep and abiding sibling rivalry" (2000, p. 22). The separation of roles may have left the Ministry of Education "unsure whether it has any overview responsibilities for specific policy issues" (Laking, Douglas, Gunaratne, Karran, Crawford-Gleeson \& Taylor, 1996, p. 18). Jesson maintained that even a former Minister of Education, Nick Smith, had more confidence in ERO than he had in his own Ministry, after his comment that if he wanted objective advice he'd go to Judith Aitken, former CEO of ERO. Smith claimed that ERO had probably been a stronger advocate for standards and excellence than the Ministry of Education (Fitchett \& Lane, 1999, p. 26). Unclear definitions of Crown expectations regarding criteria for auditing education delivery and standards in education legislation meant that ERO was responsible by default, and left as a "minder" (Austin et al., 1997, p. 16). The varying definitions and scope of ERO's responsibilities opened up "possibilities of both overlap and neglect...encouraging turf wars and defensive positioning that could increase the difficulty of policy making between the two agencies" (Robertson et al., 1997, p. 22).

The tension between ERO and the Ministry of Education may well be what allowed Metro to stay open with an unresolved future and recommendations of closure hanging over it for solong - from February 1996 to November 2001. ${ }^{15}$ Given the uncertain boundaries between ERO and the Ministry of Education, and the potential for ERO to move into policy-making areas left open by the Ministry of Education, it could be argued that the Ministry of Education had some motivation to assert its authority over ERO - both in terms of its acknowledged superior authority to decide the fate of Metro and in terms of its role to assist under-performing schools to function within the schooling system through its Schools Support Programme.

\section{Visions Beyond the Mainstream}

Late in 2000, the Ministry of Education raised the possibility that Metro could apply to be closed and re-opened as a "special character" school under section 156 of the Education Act (1989). After considering the idea, the Metro Board of Trustees decided against it since there was no guarantee that the school, once closed, would ever re-open. The Board of Trustees, along with Metro staff, felt they had good reason to be mistrustful of the processes involved in a legal change of character. They had for many years been left "hanging" on the issue of alternative education with little engagement by the Ministry of Education, and resented what they saw as the high-handed treatment by ERO. The Ministry of Education had no real alternatives left but to close Metro at the end of 2001.

In order to cater for the 26 Metro students of mandatory school attendance age, ${ }^{16}$ the Ministry of Education announced plans in early December 2001, to open two alternative units to cater for the two distinct groups of Metro students. This followed a report by a consultant contracted by the Ministry of Education. It argued that the learning needs of academically capable, non-conformist students who chose Metro for its flexibility and democratic approach, and the learning needs of at risk students for whom Metro is a "last chance" are entirely different, and that there needed to be different approaches taken for each group. Despite this, the Metro students, from both the non-conformist and at risk groups, have elected to stay together, indicating they all wish to enrol at a new unit which will open on the old Metro site in 2002 with a new name, to be governed by Mt Albert 
Grammar School. The two possible teaching positions at the new unit will be advertised, and any Metro teachers interested in working there will need to apply for the positions alongside other interested teachers.

The wish of Metro's non-conformist and at risk students to remain as a single group suggests a narrowness in current definitions of "alternative education" as associated with schooling for the at risk student, or students with behavioural or emotional difficulties. Current definitions of "alternative education" are closely related to truancy initiatives, both internationally and within New Zealand education policy (O'Rourke, 1994; Clark, Smith \& Pomare, 1996; National Research Bureau, 2000b). Certainly the alternative schools of the 1960s and 1970s progressive education movement have always attracted interest from those disaffected by, and expelled from, mainstream schools, as well as those disaffected on theoretical (philosophical) grounds. With the exception of the well-established and well-known Summerhill School, in England, ${ }^{17}$ we know comparatively little about those alternative schools which still exist today throughout Britain, the United States, and Australia, nor do we know much about what academic success and broader social destinations those students achieve, in comparison with their mainstream counterparts. ${ }^{18}$ Evidence of the success of Metro students beyond school remains anecdotal (although a number of ex-Metro students are very well-known and successful musicians, composers, and actors). Similarly, there is also little known about the achievements of alternative schooling for the at risk, and the flexibility and responsiveness of most New Zealand initiatives is largely based on pragmatism, with a lack of guidelines or theoretical base (National Research Bureau, 2000a, 2000b). ERO reports that activity centres, as a form of alternative schooling for at risk students, consider their primary aim to be the reintegration of students back into mainstream schools, although the extent to which they are successful has not been demonstrated (Education Review Office, 2001a). The activity centres' aims are consistent with the Ministry of Education's budget allocation for "alternative education", which provides for 14- and 15-year old students alienated from school, and has a stated ideal outcome as re-entry into a mainstream school (Ministry of Education, 1999). Any vision or definition of alternative education beyond a classification related to at risk students, or to a particular pathology which ostensibly needs correcting, is not currently in operation in New Zealand policy. Perhaps further research might open up new and educationally fruitful possibilities here.
Metro's future depended to some extent upon whether certain tensions between the realities of state regulation of schools and visions of cutting-edge innovation (and challenges to that regulation), within a quasi-market policy context, could be resolved. ERO acknowledged a worrying tendency for schools to become more conservative as a result of consumer pressure (Education Review Office, 1996) and Metro was beset with the implications of this as its latent popularity as a " $\operatorname{sink}$ " for at risk students became evident. Metro tried to address the relationship of school to work and the relevance of learning to life in a non-hierarchical and supportive environment. Those worlds - of work, life, and school - are bound together now in new ways that still require critical thinking about the opportunities and limitations they present. However the scope for Metro to remain at the cutting edge of thinking about these issues was severely compromised by changes to, and gaps in, education policy. Without support, research interest, peers, tools for developing good practices, and criteria for fair assessment, the job of an alternative school - to provide social and educational critique as well as provide enterprising solutions and an excellent education for its students - will be at best, thankless, and at worst, impossible.

Notes

1. In its first review of Metro in 1992, ERO noted ill-defined areas of accountability and a lack of understanding about the responsibilities of school management within the Management Committee (made up of Metro parents, students, and staff), as well as poor student attendance and the lack of systems to support curriculum delivery and student achievement (Education Review Office, 1992). In 1993 ERO noted that while considerable effort in policy development and leadership had been made toward addressing the concerns of the previous report, there was still a need to continue developing management and curriculum delivery systems and poor student attendance was still a concern. Alarm was expressed in a number of reports over the authority of Metro's school meeting to make curriculum decisions (Education Review Office, 1992, 1995, 1996a, 1996b, 1996c), particularly where decisions made there appeared to conflict with the Board's legal obligations. In its 1995 report, ERO stipulated 11 actions required for compliance with education legislation in the areas of student attendance, curriculum planning and assessment practice, teacher appraisal, finance, and health and safety (Education Review Office, 1995).

2. The first recommendations of closure occurred in February 1996 and November 1996 
3. Rosedale School (primary) opened in 1969 and Auckland Alternative Secondary School (secondary) opened in 1973 and closed in 1976.

4. Four Avenues School closed in 1993 after an ERO review claimed that accountability and a safe emotional environment for students could not be ensured because of serious discord between the Hagley Community College Board of Trustees (which governed Four Avenues, an attached unit of the College), the Four Avenues Management Committee, groups of staff, and the director, which had affected the ability of the school to operate effectively (Education Review Office, 1993).

5. No information about Ministerial Approval Clause 12 could be found in the Auckland archives, nor did any recent Auckland Metropolitan College staff or the founder or founding staff know anything about the clause. At the time of writing, Ministry of Education staff were unsure as to the origins or meaning of the clause and were conducting further investigations into the matter.

6. Metro became an independent school in its own right in 1993

7. For a fuller account of Metro's history and context within the progressive education movement, see Vaughan (2001).

8. Nearly all ERO reports on Metro, as well as the Metro monitor, made mention of the excellent pastoral systems and lack of bullying at the school.

9. ERO noted a high majority of "at risk" students at Metro (Education Review Office, 1996a, 1996c, 1998, 2000).

10. The Treasury claimed there was a "crisis" in the New Zealand economy, and identified education as one of the areas of culpability for economic problems as well as an untapped key area of economic recovery (New Zealand Treasury, 1984, 1987).

11. Some of the more controversial student-initiated school meeting votes in Metro's history have included a decision not to have school-wide evaluations of student achievement and a decision to allow smoking within the school grounds. The latter has also been successfully voted against by students in other years.

12. Until 1990, the Education Review Office was known as the Review and Audit Agency.

13. Later the 1990 (New Zealand Statutes 1990: 903) and 1993 (New Zealand Statutes 1993: 1087) amendments to the Education Act spelled out ERO's functions and the scope of its power more specifically.

14. Following much publicity and debate over ERO's role, focus on compliance, and lack of advice to schools, several reviews of ERO were completed (Austin, Parata-Blane \& Edwards 1997; Robertson, et al., 1997).
A further review recommended that ERO should contribute to the improvement process by providing guidance to schools and that ERO should, whilst remaining independent, work more closely with the Ministry of Education and government agencies to help improve educational outcomes (Mosgiel, Holden, Meade, Millar \& Smith, 2000).

15. According to the Ministry of Education's data, Metro was one of six schools to be forcibly closed between January 2001 and January 2002. The Ministry of Education does not hold data on details or lengths of time between any ERO recommendation of closure of any school and actual closure under Section 154 of the Education Act 1989, so whether Metro's experience was atypical is not known at this stage.

16. Figure taken from the 15 October roll (Ministry of Education, 2001). Briefing notes to the Secretary of Education indicate that in March 2001, the Metro roll stood at 73. Only nine students were enrolled at Years 9 and 10 respectively, the rest were enrolled at Years 11 to 13 , and the majority overall were over the age of 16 (Phillips, 2001).

17. See widespread reporting (BBC, The Guardian, The Times) throughout 1999 and 2000 of Summerhill School's successful legal battle against an OFSTED report which may have led to closure of the school. Summerhill School is a private alternative school, established in 1921 by A.S. Neill.

18. This lack of research was actually raised during the heyday of alternative schooling (Duke, 1976, 1978a, 1978b).

\section{References}

Austin, M., Parata-Blane, A., \& Edwards, W. (1997). Achieving excellence: A review of the Education External Evaluation Services. Wellington: Minister Responsible for the Education Review Office, Minister of Education, Minister of State Services.

Bremer, J. \& von Moschzisker, M. (1971). The school without walls. New York: Holt, Rinehart and Winston.

Clark, E., Smith, L., \& Pomare, M. (1996). Alternative education provision: A discussion paper commissioned by Te Puni Kokiri. Wellington: Te Puni Kokiri.

Department of Education. (1986). Inspection report on Auckland Metropolitan College, 5-7 May, 1986. Auckland: Department of Education

Duke, D. L. (1976). Challenge to bureaucracy: The contemporary alternative school. Journal of Educational Thought, 10(1), 34-48.

Duke, D. L. (1978a). Investigating unanticipated educational 
phenomena: A special plea for more research on alternative schools. Interchange on Educational Policy, 10(1), 67-81.

Duke, D. L. (1978b). The retransformation of the school: The emergence of contemporary alternative schools in the United States. Illinois: Nelson-Hall.

Education Review Office. (1992). Review report on Auckland Metropolitan College, 22 July, 1992. Auckland: ERO.

Education Review Office. (1993). Specific compliance audit report on Four Avenues Alternative School, November 1993. Christchurch: ERO.

Education Review Office. (1995). Assurance audit report on Auckland Metropolitan College, March 1995. Auckland: ERO.

Education Review Office. (1996a). Discretionary assurance audit: Report on Auckland Metropolitan College, February 1996. Auckland: ERO.

Education Review Office. (1996b). Unconfirmed discretionary assurance audit: Report on Auckland Metropolitan College, 1996. Auckland: ERO.

Education Review Office. (1996c). Discretionary assurance audit: Report on Auckland Metropolitan College, November 1996. Auckland: ERO.

Education Review Office. (1998). Discretionary review report on Auckland Metropolitan College, June 1998. Auckland: ERO.

Education Review Office. (2000). Discretionary review report on Auckland Metropolitan College, July 2000. Auckland: ERO.

Education Review Office. (2001a). Activity Centres, 4 May, 2001. Wellington: ERO.

Education Review Office. (2001b). Discretionary review report: Auckland Metropolitan College, August 2001. Auckland: ERO.

Hoskins, D. (1975, October). Reflections Upon a School. The Journal: NZ Post-Primary Teachers' Association, 42.

Jesson, J. (2000). Sideline Stan: the (h)ERO Man. New Zealand Political Review, IX(4), 22-23.

Laking, R., Douglas, C., Gunaratne, S., Karran, B., Crawford-Gleeson, K., \& Taylor, A. (1996). Ministry of Education management audit, February 1996. Wellington: State Services Commission.

Mann, E. D. G. (1989). An independent assessment of the management and functioning of Auckland Metropolitan College for the Penrose High School Board of Trustees, August 1989. Auckland: Department of Education/ Penrose High School Board of Trustees.
Middleton, S., \& May, H. (1997). Teachers talk teaching 1915-1995: Early childhood, schools and Teachers' College. Palmerston North: Dunmore Press.

Ministry of Education. (1999, November). Briefing for the incoming Minister of Education. Wellington: Ministry of Education.

Ministry of Education. (2001). Auckland Metropolitan College told it is likely to close. Media statement, October 26, 2001. Wellington: Ministry of Education.

Mosgiel, S. R., Holden, J., Meade, A., Millar, A., \& Smith, B. (2000). A review of the roles and responsibilities of the Education Review Office. Report to the Minister of Education, December 2000. Wellington: Office of the Minister of Education.

National Research Bureau. (2000a). Evaluation of alternative education. Phase two: Outcomes. Contract research: Report to the Ministry of Education, June 2000. Wellington: Ministry of Education.

National Research Bureau. (2000b). Process evaluation of school based alternative education. Contract Research: Report to the Ministry of Education, January 2000. Wellington: Ministry of Education.

New Zealand Statutes. (1990). Amendment to the Education Act 1989.

New Zealand Statutes. (1993). Amendment to the Education Act 1989, 1990.

New Zealand Treasury. (1984). Economic management: Brief to the incoming Government. Wellington: New Zealand Treasury.

New Zealand Treasury. (1987). Government management: Brief to the incoming Government, Vol II. Education Issues. Wellington: New Zealand Treasury.

O'Rourke, M. (1994, May). Children in education at risk through truancy and behavioural problems. Inquiry Report Collection. Wellington: Education and Science Committee, Ministry of Education.

Papp, B. (1976). A history of alternative schooling in New Zealand education. Unpublished masters thesis, University of Auckland.

Phillips, K. (2001). Briefing to the Secretary of Education: Update on progress at Auckland Metropolitan College. Wellington: Ministry of Education.

Robertson, S., Dale, R., Thrupp, M., Vaughan, K., \& Jacka, S. (1997). A review of ERO: Final report to the PPTA. Auckland: University of Auckland. 
Tennant, J. (2001). The learning needs of students at Auckland Metropolitan College. Draft report to the Ministry of Education. Auckland: Ministry of Education.

Vaughan, K. (2001). Out for the count: The last alternative state high school in New Zealand. Unpublished PhD thesis, School of Education, University of Auckland.

The author

Karen Vaughan is a researcher at the New Zealand Council for Educational Research (NZCER). Her research activities include further work in alternative education and a longitudinal study of Year 11 student subject choice with the introduction of the National Certificate in Educational Achievement (NCEA). Her PhD thesis, Out for the Count: The Last Alternative State High School in New Zealand, was a poststructural ethnography and Foucauldian analysis based on a five-year case study of Auckland Metropolitan College. 